\title{
Implementasi Manajemen Risiko Untuk Kredit Macet Konsumtif Di Bank Mandiri Kantor Cabang Jakarta Mampang Prapatan
}

\author{
Hardiyati Kartini Hasibuan ${ }^{1}$, Ai Annisa Utami², Khoirul Umam \\ Universitas Indraprasta PGRI Jakarta ${ }^{1,2,3}$
}

\begin{abstract}
The rapid development of the banking industry with the increasing complexity of bank business activities and increasing credit exposure, will accelerate rapidly. The bank collects funds from additional funds and distributes funds in the form of loans or funds to the people in need, both for working capital and consumption investments. Increasingly tight competition also occurs between banks with each other. Among them by issuing or launching financial services products with various types and interest rates. This research is a qualitative research by following a study conducted over a period of 1 year, describing the risk management process carried out by one of the branches of Bank Mandiri in Mampang Prapatan Jakarta, a method of data collection conducted through observation, interviews, and comparative studies of respondents who comprise from 4 people who included employees from Micro Banking Managers, Micro Credit Analysts, Micro Credit Sales, and sub-branch managers. The sampling technique used is purposive sampling. The results of the research that show the risks involved in the Micro Bank Mandiri Branch Mampang Prapatan have implemented risk management in accordance with BI regulations No.11 / 25 / PBI / 2009 and regulations made by the Directors of PT. Bank Mandiri, called the KPKD or Credit Policy. However, the application of risk management has not been carried out maximally.
\end{abstract}

Keywords: Risk Management, NPL, Bad Credit

\section{Pendahuluan}

PT. Bank Mandiri (Persero) Tbk merupakan Badan Usaha Milik Negara yang bergerak dibidang keuangan (perbankan). Selama tahun 2007 sampai dengan tahun 2014, PT. Bank Mandiri (Persero) Tbk telah meraih beragam penghargaan dari berbagai lembaga, baik dalam negeri maupun luar negeri. Penghargaanpenghargaan tersebut mencerminkan kepercayaan masyarakat kepada PT. Bank Mandiri (Persero) Tbk. Dimana Visi dari Bank Mandiri ini adalah menjadi Lembaga Keuangan Indonesia yang paling dikagumi dan selalu progresif. Misinya yang utama yaitu melayani seluruh nasabah dengan standar layanan internasional melalui penyediaan solusi keuangan yang inovatif mewujudkan pertumbuhan dan 
keuntungan yang berkesinambungan. Menjalankan proses pemberian kredit yang memperhatikan penerapan manajemen risiko.

Kredit atau pembiayaan yang diberikan oleh bank tentunya mengandung risiko, sehingga dengan demikian dalam pelaksanaannya bank harus memperhatikan asas - asas perkreditan yang sehat. Sebelum memberikan kredit, pihak bank harus yakin bahwa debitur dapat dipercaya sehingga bank harus melakukan penilaian atau analisis kredit. Di Bank Mandiri biasanya kegiatan ini dikerjakan oleh MKA (Mikro Kredit Analis). MKA melakukan analisis agar dapat meyakini bahwa bank tidak akan mengalami kerugian dikemudian hari. Salah satu risiko yang dihadapi oleh bank adalah risiko tidak terbayarnya kredit yang telah diberikan kepada debitur atau disebut dengan risiko kredit.

Risiko dan lembaga keuangan merupakan dua hal yang tidak dapat dipisahkan satu sama lainnya, karena tanpa adanya keberanian untuk mengambil risiko maka tidak akan pernah ada lembaga keuangan. Hal ini dapat dipahami karena setiap usaha maupun kegiatan yang dilakukan dapat dipastikan akan memiliki suatu risiko, baik risiko yang dapat ditangani maupun risiko yang sulit ditangani. Oleh karena itu perlu adanya pengendalian risiko agar kegiatan perbankan tetap berjalan seperti yang diharapkan, pengendalian risiko tersebut dapat dilakukan melalui sebuah proses manajemen risiko.

Kredit macet atau kredit bermasalah yang banyak terjadi tentu sangat merugikan bagi pihak bank yang telah memberikan kreditnya. Kredit masalah tersebut dapat menurunkan kinerja perbankan dan berpotensi menimbulkan kerugian bagi bank. Akibat hal tersebut maka perputaran kas menjadi tidak lancar, bank tidak akan lagi bisa untuk memberikan kredit kepada nasabah lain dalam jumlah yang besar dikarenakan pihak bank sendiri mengalami kesulitan perputaran arus kas. Keadaan seperti ini membuat bank tidak lagi mampu membayar utang jangka pendeknya sehingga bank tidak lagi dapat memenuhi likuiditasnya atau dalam keadaan tidak likuid. Selain itu, kredit macet / bermasalah akan mengurangi laba dari bank yang bersangkutan. Jika laba berkurang maka akan berpengaruh terhadap bonus atau insentif para karyawan.

Oleh karena itu, mengingat dampak yang timbulkan kredit macet sangat 
berpengaruh pada performa bank tersebut, maka kredit macet / bermasalah tersebut harus segera diatasi. Untuk itu bank seharusnya dapat mengelola manajemen risiko dengan baik. Manajemen risiko merupakan suatu bidang ilmu yang membahas tentang bagaimana suatu organisasi menerapkan ukuran dalam memetakan berbagai permasalahan yang ada dengan menempatkan berbagai pendekatan manajemen secara komprehensif dan sistematis.

PT. Bank Mandiri (Persero) Tbk Cabang Mampang Prapatan merupakan salah satu lembaga keuangan yang memperoleh pendapatan berupa bunga yang diterima dari debitur. Untuk itu dibawah ini peneliti melampirkan data tentang kredit macet pada PT. Bank Mandiri Cabang Mampang Prapatan periode Januari 2016 s.d Desember 2016 sebagai berikut:

\section{Gambar 1.1 Angka Kredit Macet Mikro Bank Mandiri Cab. Mampang Prapatan ( Dalam juta rupiah per Tahun 2016 )}

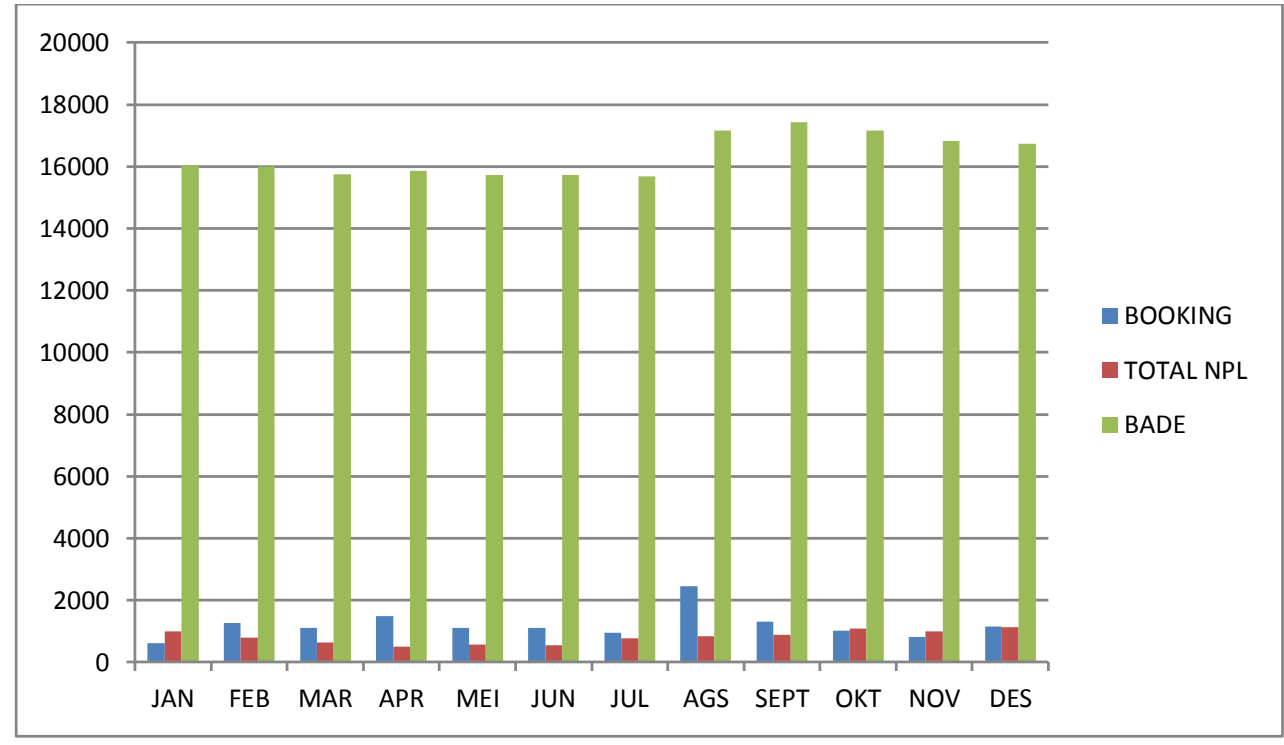

Dari data diatas, dapat dilihat bahwa jumlah kredit bermasalah mengalami penurunan serta kenaikan yang fluktuatif. Dibulan Januari total kredit bermasalah cukup tinggi yaitu mencapai Rp 993.000.000 namun dibulan Februari hingga April sedikit mengalami penurunan, nilai kredit bermasalah menjadi Rp 797.000.000, Rp 635.000.000 dan Rp 506.000.000. Dari bulan Mei hingga Desember jumlah kredit bermasalah cenderung meningkat meskipun dibulan Juni ada penurunan. Kredit 
bermasalah atau Non Performing Loan mencapai angka tertinggi di bulan Desember 2016 yaitu sebesar Rp 1.135.000.000 dan angka terendah di bulan April 2016 sebesar Rp 506.000.000.

\section{Tinjauan Pustaka}

Kredit berasal dari bahasa Romawi " credere " yang artinya percaya. Dalam bahasa Belanda istilahnya " vertrouwen ", dalam bahasa Inggris " believe " atau " trust " atau " confidence ", yang semuanya berarti percaya. Jika dihubungkan dengan bank, maka terkandung pengertian bahwa bank selaku pemberi kredit percaya untuk meminjamkan sejumlah uang kepada nasabah karena debitur dapat dipercaya kemampuannya untuk membayar lunas pinjamannya setelah jangka waktu tertentu.. Menurut Undang-Undang No. 10 Tahun 1998 tentang perbankan (revisi UU No. 14 Tahun 1992) yang menyebutkan bahwa:"Kredit adalah penyediaan uang atau tagihan yang dapat dipersamakan dengan itu, berdasarkan persetujuan pinjam-meminjam antara pihak bank dengan pihak lain, peminjam berkewajiban melunasi hutangnya setelah jangka waktu tertentu dengan jumlah bunga atau bagi hasil yang telah ditetapkan “.Berdasarkan pengertian tersebut maka dapat dijelaskan bahwa dalam aktivitas perkreditan terdapat unsur kepercayaan, kesepakatan, jangka waktu, risiko, dan balas jasa. Dalam kredit ada unsur jangka waktu antara penyerahan dengan pelunasan, karena itu selama jangka waktu tersebut terdapat risiko kredit macet atau kredit bermasalah.

\section{Penggolongan Kualitas Kredit}

Dendawijaya (2001) menyebutkan beberapa pengertian mengenai kategori kolektibilitas kredit berdasarkan ketentuan yang dibuat Bank Indonesia, sebagai berikut:

a. Kredit Lancar

b. Kredit Kurang Lancar.

c. Kredit Diragukan

d. Kredit Macet

Kredit yang pengembalian pokok pinjaman dan pembayaran bunganya telah mengalami penundaan lebih dari satu tahun sejak jatuh tempo menurut jadwal yang telah diperjanjikan. 


\section{Jenis-jenis Risiko}

Joel G. Siegel dan Jae K. Shim dalam Irham Fahmi (2011:2) mendefinisikan risiko bank adalah kombinasi dari tingkat kemungkinan sebuah peristiwa terjadi disertai konsekuensi (dampak) dari peristiwa tersebut pada bank. Setiap kegiatan mengandung potensi sebuah peristiwa terjadi atau tidak terjadi, dengan konsekuensi yang memberi peluang untuk untung (upside) atau mengancam sebuah kesuksesan (downside).

Risiko kredit adalah risiko akibat kegagalan debitur dan atau pihak lain didalam memenuhi kewajibannya kepada bank. Risiko kredit dapat bersumber dari berbagai aktivitas fungsional bank seperti perkreditan (penyediaan dana), treasury dan investasi, dan pembiayaan perdagangan, yang tercatat dalam trading book maupun dalam banking book. Contohnya timbulnya kredit macet, presentase piutang meningkat.

\section{Pengertian dan Manfaat Manajemen Risiko}

Manajemen risiko adalah kegiatan kunci bagi suatu organisasi. Manajemen risiko yang berhasil akan menjamin pencapaian tujuan organisasi secara efektif dan efisien. Manajemen risiko membantu pengambilan keputusan dengan mempertimbangkan ketidakpastian dan pengaruhnya terhadap pencapaian tujuan. Adapun pengertian Manajemen Risiko dalam Peraturan Bank Indonesia No.11/25/PBI/2009 Pasal 1 bagian 5 yaitu: “ Manajemen risiko adalah serangkaian metedologi dan prosedur yang digunakan untuk mengidentifikasi, mengukur, memantau, dan mengendalikan risiko yang timbul dari seluruh kegiatan usaha bank“.

Menurut Djohanputro (2008:43) Manajemen risiko merupakan proses terstruktur dan sistematis dalam mengidentifikasi, mengukur, memetakan, mengembangkan alternatif penanganan risiko, dan memonitor dan mengendalikan penanganan risiko. Menurut Fahmi (2011:12) Manajemen risiko adalah suatu bidang ilmu yang membahas tentang bagaimana suatu organisasi menerapkan ukuran dalam memetakan berbagai permasalahan yang ada dengan menempatkan 
berbagai pendekatan manajemen secara komprehensif dan sistematis. Menurut Darmawi (2014:2) Manajemen risiko adalah proses pengukuran atau penilaian risiko serta pengembangan strategi pengelolaannya. Strateginya mulai dari mengidentifikasi risiko, mengukur dan menentukan besarnya risiko, lalu mencari jalan bagaimana menangani risiko tersebut.

\section{Manajemen Risiko dalam Pengelolaan Risiko Kredit}

Risiko kredit (credit risk) adalah risiko akibat kegagalan debitur dan atau pihak lain dalam dalam memenuhi kewajibannya kepada bank. Singkat kata risiko kredit adalah kerugian bagi bank karena debitur tidak melunasi kembali pokok pinjamannya plus bunganya (Ali,2006:199). Kepentingan bank dalam kaitannya dengan risiko kredit, yaitu bank berusaha agar rate of return dari kredit yang diberikan bank adalah maksimum.

Tujuan dari manajemen risiko kredit adalah untuk maksimalisasi tingkat pengembalian kredit bank dengan menjaga credit risk exposure. Untuk mencapai itu diperlukan kepiawaian bank dalam mengelola perkreditannya. Manajemen bank dalam mengelola risiko kredit haruslah berdasarkan prinsip-prinsip manajemen risiko yang telah teruji. Bank for international Settlement mengemukakan prinsipprinsip manajemen risiko kredit sebagai acuan dalam melakukan review terhadap risiko kredit yang dikelola bank.

\section{Metodologi Penelitian}

Metode yang dilakukan dalam penelitian ini adalah metode penelitian kualitatif dengan pendekatan follow up study. Populasi dalam penelitian ini adalah karyawan PT. Bank Mandiri (Persero), Tbk Cab Jakarta Mampang Prapatan. Sampel dalam penelitian kualitatif bukan dinamakan responden, tetapi sebagai narasumber, atau partisipan, informan, teman, dan guru dalam penelitian (Sugiyono, 2010:390). Sampel yang dipilih oleh peneliti 4 orang karyawan Mikro Bank Mandiri Cab. Mampang Prapatan yaitu terdiri dari 1 orang Mikro Banking Manager, 1 orang Mikro Kredit Analis, dan 1 orang Mikro Kredit Sales, dan 1 orang sub branch manager. Teknik Sampling yang digunakan adalah Purposive Sampling.

Dalam penelitian ini penulis memperoleh data melalui data primer, yaitu data masih mentah yang dikumpulkan dan diolah sendiri oleh peneliti langsung dari 
subjek atau objek penelitian. Sesuai dengan pokok masalah dalam penelitian mengenai evaluasi penerapan manajemen risiko pada tingkat kredit macet, maka metode pengumpulan data yang penulis gunakan dalam penelitian ini adalah observasi, wawancara dan dokumentasi.

Data Responden

Responden dalam penelitian ini adalah karyawan Mikro Bank Mandiri Mampang. Dalam penelitian ini responden dilihat dari beberapa sisi, diantaranya adalah identitas responden berdasarkan jabatan responden, jenis kelamin responden, tingkat pendidikan responden, dan lamanya masa bekerja responden. Berikut ini merupakan tabel identitas responden.

Tabel 1. Identitas Responden

\begin{tabular}{|l|l|l|l|}
\hline Jabatan & Jenis Kelamin & Tingkat pendidikan & Lama Bekerja \\
\hline SBM & Pria & S1 & 10 Tahun \\
\hline Manajer & Pria & S1 & 5 tahun \\
\hline MKA & Pria & S1 & 5 tahun \\
\hline MKS & Pria & SMA & 5 tahun \\
\hline MKS & Pria & SMA & 5 tahun \\
\hline
\end{tabular}

Tabel diatas menunjukan bahwa responden terdiri dari Manajer, Mikro Kredit Analis, dan Mikro Kredit Sales. Semua responden di Mikro Bank Mandiri Mampang yang berjumlah empat orang berjenis kelamin pria. Terdapat dua orang responden yang sudah bekerja lebih dari 5 tahun, dan dua orang lainnya bekerja kurang dari 5 tahun. Data diatas juga menunjukan bahwa responden Mikro Bank Mandiri Cabang Mampang berpendidikan SMA hingga S1, Jumlah responden tersebut adalah key informan yang ada di Mikro Bank Mandiri Mampang.

\section{Hasil Dan Pembahasan}

Penerapan manajemen risiko di Bank Mandiri didukung dengan kerangka yang mencakup kebijakan dan prosedur manajemen risiko serta limit risiko yang ditetapkan secara jelas dan sejalan dengan visi, misi, dan strategi bisnis Bank Mandiri serta perundang-undangan yang berlaku. Penetapan limit risiko telah memadai, yang meliputi limit per produk/transaksi, perjenis risiko, dan per aktivitas fungsional dan melakukan limit monitoring secara periodik. 
Bank Mandiri juga melaksanakan sistem pengendalian intern dalam penerapan manajemen risiko bank dengan mengacu kepada kebijakan dan prosedur yang telah ditetapkan. Bank memiliki penetapan wewenang dan tanggung jawab pemantauan kepatuhan, kebijakan, prosedur, dan limit. Satuan kerja audit intern Bank Mandiri melakukan audit secara berkala dengan cakupan yang memadai, mendokumentasikan temuan audit, serta melakukan review terhadap tindak lanjut temuan audit. Kemudian satuan kerja Bank Mandiri dapat langsung membenahi hasil temuan audit yang sekiranya dapat merugikan perusahaan secara keseluruhan. Salah satu indikator yang digunakan untuk menghitung angka kredit macet adalah dengan penghitungan NPL. NPL atau Non Performing Loan adalah kredit-kredit yang digolongkan kedalam kolektibilitas 3,4, dan 5 sebagaimana diatur pada Peraturan Bank Indonesia NO.7/2/PBI tanggal 20 Januari 2005 mengenai Kualitas Aktiva Produktif beserta perubahannya. Berikut ini adalah data perkembangan NPL selama tahun 2016.

Tabel 2. Presentase NPL Mikro Bank Mandiri Mampang Selama Tahun 2016

\begin{tabular}{|l|c|l|l|lc|}
\hline \multicolumn{1}{|c|}{ Bulan } & Baki Debet & Total Kredit Macet & NPL & \multicolumn{2}{|c|}{ Kenaikan / Penurunan NPL } \\
\hline Januari & Rp 16.036.000.000 & Rp 993.000.000 & $6,20 \%$ & - & \\
\hline Februari & Rp 15.996.000.000 & Rp 797.000.000 & $4,98 \%$ & $\Downarrow$ & $1,22 \%$ \\
\hline Maret & Rp 15.749.000.000 & Rp 635.000.000 & $4,03 \%$ & $\Downarrow$ & $0,95 \%$ \\
\hline April & Rp 15.867.000.000 & Rp 506.000.000 & $3,18 \%$ & $\Downarrow$ & $0,85 \%$ \\
\hline Mei & Rp 15.737.000.000 & Rp 559.000.000 & $3,55 \%$ & $\Uparrow$ & $0,37 \%$ \\
\hline Juni & Rp 15.737.000.000 & Rp 552.000.000 & $3,50 \%$ & $\Downarrow$ & $0,05 \%$ \\
\hline Juli & Rp 15.692.000.000 & $\operatorname{Rp~773.000.000~}$ & $4,92 \%$ & $\Uparrow$ & $1,42 \%$ \\
\hline Agustus & Rp 17.158.000.000 & $\operatorname{Rp~829.000.000~}$ & $4,83 \%$ & $\Downarrow$ & $0,09 \%$ \\
\hline September & $\operatorname{Rp~17.426.000.000~}$ & $\operatorname{Rp~879.000.000~}$ & $5,04 \%$ & $\Uparrow$ & $0,21 \%$ \\
\hline Oktober & $\operatorname{Rp~17.172.000.000~}$ & $\operatorname{Rp~1.079.000.000~}$ & $6,28 \%$ & $\Uparrow$ & $1,24 \%$ \\
\hline November & $\operatorname{Rp~16.822.000.000~}$ & $\operatorname{Rp~1.000.000.000~}$ & $5,94 \%$ & $\Downarrow$ & $0,34 \%$ \\
\hline Desember & $\operatorname{Rp~16.739.000.000}$ & $\operatorname{Rp~1.135.000.000~}$ & $6,78 \%$ & $\Uparrow$ & 0,84 \\
\hline
\end{tabular}

Berikut ini gambaran follow up study mitigasi dan manajemen resiko yang dilakukan manajemen terhadap tingkat kredit macet yang diukur dengan nilai NPL di Bank Mandiri Cabang Mampang Prapatan Jakarta selama 12 bulan. Dimulai dari data NPL bulan Januari -Februari. 
Tabel 3. Perubahan angka NPL dari bulan Januari - Februari

\begin{tabular}{|l|c|c|c|l|}
\hline \multicolumn{1}{|c|}{ Bulan } & $\begin{array}{c}\text { Baki Debet } \\
(\mathrm{A})\end{array}$ & $\begin{array}{c}\text { Total KOL 3,4,5 } \\
(\mathrm{B})\end{array}$ & $\begin{array}{c}\text { NPL } \\
(\mathrm{C})\end{array}$ & $\begin{array}{c}\text { Kenaikan / Penurunan } \\
\text { NPL }\end{array}$ \\
\hline Januari & $\mathrm{Rp} \mathrm{16.036.000.000}$ & $\mathrm{Rp} \mathrm{993.000.000}$ & $6,20 \%$ & - \\
\hline Februari & $\mathrm{Rp} \mathrm{15.996.000.000}$ & $\mathrm{Rp} \mathrm{797.000.000}$ & $4,98 \%$ & $1,22 \%$ \\
\hline
\end{tabular}

NPL (C) dibulan Januari $=($ B : A ) $x 100 \%$

NPL (C) dibulan Januari $=($ Rp 993.000.000 : Rp 16.036.000 $) \times 100 \%$

$$
=0,062 \times 100 \%=6,20 \%
$$

$\mathrm{A}=$ Baki Debet ( saldo pokok dari plafon pinjaman yang disepakat)

$\mathrm{B}=$ Total Kredit Macet(Total Kredit yang mengalami penundaan pembayaran)

$\mathrm{C}=$ NPL ( Non Performing Loan )

Terjadi penurunan nilai NPL dari bulan Januari ke bulan Februari sebesar 1,22\%.

Prinsip Kehati-hatian yang dimiliki Bank Mandiri tertera dalam KPKD atau

Kebijakan Perkreditan yang menjadi pedoman yang harus dilakukan disetiap unit kerja. Prinsip Kehatian-hatian tersebut meliputi:
1) Four-Eye Principle
2) Prinsip Konsolidasi Eksposur
3) Prinsip One Obligor
4) Prinsip Mengenal Nasabah (Know Your Customer)
5) Self Financing
6) Prinsip Dasar Evaluasi Kredit
7) Prinsip Penetapan Kualitas Aktiva Produktif
8) Prinsip Monitoring dan Pengawasan Kredit
9) Prinsip Pengelolaan dan Penyelesaian Kredit Bermasalah

Tabel 4. Perubahan nilai NPL dari bulan Februari - Maret

\begin{tabular}{|l|c|c|c|cc|}
\hline \multicolumn{1}{|c|}{ Bulan } & Baki Debet & $\begin{array}{c}\text { Total Kredit } \\
\text { Macet }\end{array}$ & NPL & $\begin{array}{c}\text { Kenaikan / } \\
\text { Penurunan NPL }\end{array}$ \\
\hline Februari & $\operatorname{Rp~15.996.000.000~}$ & $\operatorname{Rp~797.000.000~}$ & $4,98 \%$ & $\Downarrow$ & $1,22 \%$ \\
\hline Maret & $\operatorname{Rp~15.749.000.000}$ & $\operatorname{Rp~635.000.000~}$ & $4,03 \%$ & $\Downarrow$ & $0,95 \%$ \\
\hline
\end{tabular}


Nilai NPL sebanyak 0,95\% menurun dari bulan Februari ke bulan Maret. dibulan Maret banyak pencairan kredit pengajuan dari debitur yang melakukan top-up. Topup kredit dilakukan oleh debitur yang sudah mengajukan kredit minimal sudah membayar 6 kali angsuran tentu saja dalam kategori kolektibilitas lancar. Sehingga prinsip mengenal nasabah (Know Your Customer) yang ada didalam KPKD (Kebijakan Perkreditan) Bank Mandiri tentu sudah dijalankan sesuai dengan kebijakan yang dibuat. Dalam KPKD Bank Mandiri Prinsip KYC wajib dimiliki oleh setiap unit kerja yang terkait. Tata cara mengenal nasabah berpedoman kepada ketentuan Regulator/Otoritas Perbankan serta ketentuan Bank yang mengatur mengenai prinsip mengenal nasabah dimana pelaksanaannya dilakukan melalui checking. Dengan menerapkan prinsip KYC ini tentunya unit akan dapat menurunkan nilai NPL karena sudah memastikan bahwa nasabah yang melakukan top-up merupakan debitur yang kreditnya tergolong kolektibilitas lancer. "Mengenal nasabah atau calon debitur merupakan hal pokok yang juga tercantum dalam Pasal 1 ayat 2 PBI No. 5/21/PBI/2003 tentang penerapan prinsip mengenal nasabah yang berbunyi, “ Prinsip yang diterapkan Bank untuk mengetahui identitas nasabah, memantau kegiatan transaksi nasabah, termasuk pelaporan transasksi yang mencurigakan. “

Penurunan nilai NPL juga terjadi dari bulan Maret-April sebanyak 0,85\%. penurunan nilai NPL ini karena dibulan April calon debitur yang mengajukan kredit memiliki prospek usaha yang cukup bagus. Sehingga sebelum terjadinya akad kredit unit mikro telah menjalankan prinsip penetapan kualitas aktiva produktif terhadap calon debitur. Penilaian ini ditetapkan sesuai ketentuan Regulator/Otoritas Perbankan yaitu atas faktor prospek usaha dan kinerja debitur. Oleh karena itu dibulan April unit Mikro dapat menurunkan nilai NPL. " Penilaian kualitas aktiva produktif menurut Dahlan Siamat (2004:136) “ Kualitas aktiva produktif bank dinilai berdasarkan pada:

a. Ketepatan pembayaran kembali pokok dan bunga serta kemampuan peminjam yang ditinjau dari keadaan usaha yang bersangkutan untuk kredit yang diberikan. 
b. Tingkat kemungkinan diterimanya kembali dana yang ditanamkan untuk surat berharga."

Tabel 5. Perubahan nilai NPL dari bulan April - Mei

\begin{tabular}{|l|c|c|c|cc|}
\hline \multicolumn{1}{|c|}{ Bulan } & Baki Debet & $\begin{array}{c}\text { Total Kredit } \\
\text { Macet }\end{array}$ & NPL & \multicolumn{2}{c|}{$\begin{array}{c}\text { Kenaikan / } \\
\text { Penurunan NPL }\end{array}$} \\
\hline April & Rp 15.867.000.000 & Rp 506.000.000 & $3,18 \%$ & $\Downarrow$ & $0,85 \%$ \\
\hline Mei & Rp 15.737.000.000 & Rp 559.000.000 & $3,55 \%$ & $\Uparrow$ & $0,37 \%$ \\
\hline
\end{tabular}

Dibulan Mei terlihat ada kenaikan nilai NPL sebanyak 0,37\% setelah tiga bulan berturut-turut nilai NPL mengalami penurunan. kenaikan NPL ini terjadi karena tidak berjalannya four-eye principle dengan baik. MKS cenderung lebih memberikan kemudahan bagi calon debitur dalam pengajuan kredit, seperti persyaratan yang diberikan oleh calon debitur belum lengkap tetapi kredit sudah diajukan kepada komite kredit. Dalam hal ini unit tidak menjalankan mekanisme pengajuan kredit sesuai dengan Kebijakan Perkreditan Bank Mandiri. "Dokumen merupakan hal yang wajib dilengkapi oleh calon debitur dalam pengajuan kredit. Apabila dokumen yang disertakan belum lengkap tetapi pencairan kredit tetap dilakukan, maka ini akan menimbulkan risiko dalam penberian kredit seperti yang dikemukakan oleh Kuncoro \& Suhardjono (2011:223) “ Prosedur pemberian kredit yang sehat adalah upaya bank dalam mengurangi risiko dalam pemberian kredit yang dimulai dengan tahap penyusunan perencanaan perkreditan, dilanjutkan dengan proses pemberian putusan kredit (prakarsa, analisis dan evaluasi, negoisasi, rekomendasi, dan pemberian putusan kredit), penyusunan perjanjian kredit, dokumen dan administrasi kredit, persetujuan pencairan kredit serta pengawasan dan pembinaan kredit. “

Nilai NPL dibulan Juni menurun sebesar $0,05 \%$. Hal ini sebabkan karena dibulan Juni ini merupakan bulan raport Bank Mandiri. Setiap cabang memiliki target minimal pencapaian asset maupun liabilities. Agar cabang tidak memiliki raport yang merah maka setiap unit kerja akan memaksimalkan kinerjanya. Target tersebut meliputi tabungan, giro, deposito, dan kredit. Oleh karena itu, MKS bekerja 
maksimal dalam penagihan dan segala sesuatu yang berhubungan dengan nilai NPL agar NPL dibulan Juni tidak sama atau tidak lebih tinggi dari bulan sebelumnya. "Ukuran-ukuran dari pencapaian target yang dikemukakan oleh Nawawi dan Martini dalam bukunya Administrasi Personil Untuk Peningkatan Produktivitas Kerja (1990:99) adalah " Pencapaian target sesuatu yang dihasilkan dalam jangka waktu yang telah ditetapkan, tingkat pendayagunaan dan kemanfaatan suatu hasil yang dicapai, dan hasil kerja.“

Kenaikan NPL yang terjadi dibulan Juli cukup tinggi yaitu mencapai 1,42 $\%$. Hal ini disebabkan oleh kurangnya monitoring terhadap prospek usaha debitur dan tidak dilakukannya review atas fasilitas kredit yang telah diberikan kepada debitur. Sehingga unit tidak mengetahui apakah debitur menggunakan fasilitas kredit sesuai dengan tujuan pengajuan kreditnya. Tentu saja unit tidak menjalankan dengan baik prinsip monitoring dan pengawasan kredit yang telah dibuat oleh management Bank Mandiri. “ Tjoekam (1999:220) menyatakan bahwa "pengawasan kredit adalah usaha untuk mengetahui dan menyusun strategi perbaikan secara dini indikasi-indikasi penyimpangan (deviation) dari kesepakatan bank dan debitur dalam proses kegiatan perkreditan, yang kemudian menjadi penyebab kredit bermasalah dan mendatangkan kerugian bagi bank dan debitur.“

Nilai NPL bulan Agustus menurun 0,09\% dari kenaikan sebelumnya yang mencapai $1,42 \%$. kenaikan NPL dibulan Juli yang cukup tinggi membuat unit bekerja lebih keras. Hingga akhirnya unit menawarkan program restrukturisasi kepada debitur. Program restrukturisasi ini merupakan langkah yang diambil dalam penanganan kredit macet atau kredit bermasalah. Program ini bisa digunakan jika debitur yang melakukan pengajuan kepada komite kredit. Restrukturisasi kredit ini adalah penjadwalan ulang kredit debitur, dengan memperpanjang jangka waktu atau tenor kredit, sehingga secara otomatis angsuran setiap bulannya bisa lebih kecil dari sebelumnya. Dalam hal ini unit Mikro Cabang Mampang telah menjalankan prinsip pengelolaan dan prinsip penyelesaian kredit bermasalah dengan baik. "Dengan penanganan yang tepat dan dilakukan oleh orang yang tepat maka kredit macet dapat diatasi. Menurut Muchdarsyah(1995:120) "Pengelolaan kredit macet sebaiknya ditangani oleh staf yang sudah cukup berpengalaman serta objektif dalam 
memberikan penilaian.“

Nilai NPL dibulan September mengalami keniakan sebesar 0,21\% hal ini disebabkan oleh pencairan kredit yang ada dibulan September merupakan pencairan dari pengajuan debitur walk in customer. Kurangnya prinsip kehati-hatian yang dilakukan oleh unit Mikro terhadap debitur walk in customer menyebabkan naiknya nilai NPL dibulan September. Hal ini disebabkan oleh pendapatan debitur yang berkurang dikarenakan usahanya yang sudah tutup. Sehingga debitur tidak bisa membayar kreditnya sesuai dengan nominal angsuran setiap bulannya. " Oleh karena itu dengan calon debituryang tergolong walk in customer unit Mikro harus melakukan pendekatan guna lebih mengenal calon debitur. Seperti yang dikemukakan oleh Nindyo Pramono ( 2006:218-219) "bank diharapkan tidak hanya mengenal nasabah secara harfiah saja, tapi bisa mengenal lebih komprehensif lagi, tidak hanya mengetahui identitas nasabah taoi juga berkaitan dengan profil dan karakter transaksi nasabah, yang dilakukan melalu jasa perbankan.

Kenaikan NPL dibulan Oktober cukup besar, yakni 1,24\%. hal ini terjadi karena beberapa aspek dalam prinsip kehati-hatian Kebijakan Perkreditan Bank Mandiri tidak dijalankan maksimal di unit Mikro Cabang Mampang. Mulai dari kurangnya monitoring terhadap kredit debitur yang sedang berjalan, klasifikasi usaha debitur yang tidak sesuai, seperti usaha yang memiliki resiko tinggi tidak ada penanganan khusus. Program restrukturisasi kredit yang tadinya diharapkan dapat menurunkan nilai NPL pun tidak berpengaruh banyak dikarenakan usaha debitur yang sudah tutup sehingga tidak dapat mengajukan program restrukturisasi. "Monitoring atau pengawasan dalam kredit merupakan hal yang paling utama. Pengawasan mencakup upaya memeriksa, apakah semua yang terjadi sesuai rencana yang ditetapkan, perintah yang dikeluarkan dan prinsip yang dianut, juga dimaksudkan untuk mengetahui kelemahan dan kesalahan agar dapat dihindari kejadiannya dikemudian hari. Seperti yang dikatakan oleh H. Sofyan Safri (2001:10), pengawasan adalah segala usaha dan kegiatan untuk mengetahui dan menilai kenyataan yang sebenarnya mengenai pelaksanaan tugas atau kegiatan apakah sesuai dengan yang semestinya atau tidak.

Dibulan selanjutnya nilai NPL turun $0,34 \%$, dibulan November ini unit 
Mikro berusaha untuk dapat menurunkan nilai NPL. Unit mikro lebih selektif dalam melakukan proses pencairan kredit yang dilakukan oleh debitur. Seperti melakukan reminder system atas setiap ketidaklengkapan dokumen debitur. Juga melakukan stress test terhadap portofolio kredit akibat perubahan yang terjadi seperti kurs atau suku bunga. Dalam hal ini unit sudah menjalankan prinsip kehati-hatian sesuai KPKD Bank Mandiri yaitu melakukan antisipasi resiko, melalui sistem deteksi dini atau Early Recognition Watch List. “

Tabel 6. Perubahan nilai NPL dari bulan November - Desember

\begin{tabular}{|c|c|c|c|c|}
\hline Bulan & Baki Debet & $\begin{array}{c}\text { Total Kredit } \\
\text { Macet }\end{array}$ & NPL & $\begin{array}{c}\text { Kenaikan / } \\
\text { Penurunan NPL }\end{array}$ \\
\hline November & Rp 16.822.000.000 & Rp 1.000.000.000 & $5,94 \%$ & $\Downarrow \quad 0,34 \%$ \\
\hline Desember & Rp 16.739.000.000 & $\operatorname{Rp} 1.135 .000 .000$ & $6,78 \%$ & 0,84 \\
\hline
\end{tabular}

Dibulan Desember terlihat kenaikan NPL sebesar 0,84\%, naiknya NPL diakhir tahun ini disebabkan oleh kondisi ekonomi debitur yang kurang baik. Unit Mikro kesulitan menjalankan prinsip pengelolaan dan penyelesaian kredit bermasalah. Adanya penambahan satuan kerja khusus yang difokuskan dalam penagihan juga tidak banyak memberikan pengaruh terhadap nilai NPL. Cara terakhir yang digunakan guna menutupi sisa hutang debitur yaitu dengan melakukan penarikan agunan dan menjualnya. Akan tetapi hasil jual agunan pun tidak dapat menutupi sisa kredit debitur beserta bunganya. Sehingga tidak berpengaruh banyak terhadap nilai NPL. " seperti yang tercantum dalan Peraturan Bank Indonesia No.7/2/PBI/2005 “ Pada kredit yang bersifat struktural pada umumnya tidak dapat diselesaikan dengan restrukturisasi sebagaimana kredit bermasalah yang bersifat nonstructural, melainkan harus diberikan pengurangan pokok kredit (hair cut) agar usahanya dapat berjalan kembali dan pendapatananya mampu untuk memenuhi kewajiban-kewajibannya."

Dalam mengelola risiko Mikro Bank Mandiri Cabang Mampang Prapatan sudah menerapkan manajemen risiko sesuai dengan peraturan BI No.11/25/PBI/2009 dan peraturan yang telah dibuat oleh Direksi PT. Bank Mandiri yang disebut dengan KPKD atau Kebijakan Perkreditan. Akan tetapi penerapan manajemen risiko tersebut belum dilakukan secara maksimal. Seluruh jajaran Bank Mandiri yang terkait dengan perkreditan harus memiliki pandangan dan persepsi 
yang sama dalam menangani kredit bermasalah atau kredit macet, dengan pendekatan sebagai berikut:

1. Tidak membiarkan atau bahkan menutup-nutupi adanya kredit bermasalah.

2. Adanya kemampuan mendeteksi secara dini adanya kredit macet atau diduga akan menjadi kredit macet.

3. Penanganan atas adanya kredit macet atau diduga akan menjadi kredit macet harus dilakukan secara dini dan sesegera mungkin.

4. Tidak melakukan penyelesaian kredit macet dengan melakukan plafondering kredit sebagai window dressing.

5. Tidak diizinkan melakukan pengecualian dalam penyelesaian kredit macet, khususnya untuk pihak yang terkait dengan bank dan debiturdebitur besar tertentu.

\section{Kesimpulan}

Secara keseluruhan, manajemen risiko yang telah ditetapkan oleh PT. Bank Mandiri (persero), Tbk yang juga tertera dalam Kebijakan Perkreditan telah sesuai guna mencegah, mengurangi, dan menanggulangi segala kemungkinan resiko yang terjadi pada Bank. Akan tetapi, Mikro Bank Mandiri Cabang Mampang belum maksimal dalam menerapkan manajemen risiko disetiap aktivitas kreditnya. Adapun faktor penyebab terjadinya risiko kredit yang bermasalah disebabkan oleh Sumber Daya Manusia yaitu nasabah atau debitur yang bersangkutan dan juga kurangnya pengawasan internal oleh unit mikro. Sebagaimana yang telah ditetapkan dalam Kebijakan Perkreditan (KPKD) yang ada di Bank Mandiri tentang prinsip kehati-hatian dan prinsip pengawasan kredit belum dapat terlaksana dengan baik di Mikro Cabang Mampang. Sehingga hal tersebut menyebabkan naik dan turunnya angka kredit macet yang diperoleh Mikro Cabang Mampang disetiap bulannya sepanjang tahun 2016.

Diharapkan dimasa yang akan datang penelitian ini dapat digunakan sebagai salah satu sumber data untuk penelitian selanjutnya. Peneliti selanjutnya juga diharapkan dapat memperluas area surveynya agar dapat mengetahui apakah setiap unit terkait sudah menjalankan semua prinsip dalam manajemen risiko Bank 
Mandiri. Selain itu diharapkan penelitian selanjutnya dapat memberikan solusi yang dapat dijalankan oleh perusahaan.

\section{DAFTAR PUSTAKA}

Bank Indonesia. (2003). Surat Edaran Bank Indonesia:No.5/21/DPNP tanggal 29September 2003. Perihal Penerapan Manajemen Risiko Bagi Bank Umum. Jakarta.

Darmawi, Herman. (2010). Manajemen Risiko, Cetakan ke-14. Jakarta: PT. Bumi Aksara

Djohanputro, Bramantyo. (2008). Manajemen Risiko Korporat. Jakarta: Penerbit PPM

Fahmi, Irham. (2011). Manajemen Risiko : Teori, Kasus, dan Solusi. Bandung: Alfabeta CV

Kasmir. (2014). Manajemen Perbankan, Edisi Revisi. Jakarta : PT Raja Grafindo Persada.

Sugiyono. (2008). Metode Penelitian Kuantitatif, Kualitatif dan R\&D. Bandung: Alfabeta

Sugiyono. (2010). Metode Penelitian Kuantitatif, Kualitatif dan R\&D. Bandung: Alfabeta.

Sugiyono. (2013). Metode Penelitian Kuantitatif, Kualitatif dan R\&D. Bandung: Alfabeta.

Undang-Undang Pokok Perbankan Nomor 10 Tahun 1998

Undang-Undang Pokok Perbankan Nomor 10 Tahun 1998

Wahid, Abdul. 2013. Rancangan Penelitian Deskriptif, Kalimantan Selatan. (http://daun2001.blogspot.com/2013/05/rancangan-penelitian-deskriptif.html, diakses tanggal 16 November 2014). 